Archived version from NCDOCKS Institutional Repository http://libres.uncg.edu/ir/asu/

\title{
Appalachïan
}

B O O N E, N O R T H C A R O L I N A

\section{Reference Letters And The Uninformed Business Educator: A U.S. Legal Perspective}

\author{
By: Nina Compton and Pia A. Albinsson
}

\begin{abstract}
While providing references to students, business professors have to meet dual demands of giving sincere references to prospective employers while avoiding any potential litigation claims of "defamation" and "violation of privacy" from the students. While the approach of providing bare minimum information may seem to mitigate the risk of litigation claims of defamation from former students, it might serve as a potential pitfall for facing "intentional misrepresentation" liability from the prospective employer. This paper addresses these concerns, together with other legal issues U.S. business educators face in this area of potential liability. Suggestions are offered to those who provide references for the purpose of minimizing the possibility of litigation exposure, either from the student or from his future employer.
\end{abstract}

Compton, Nina and Albinsson, Pia A. (2013) "REFERENCE LETTERS AND THE UNINFORMED BUSINESS EDUCATOR: A U.S. LEGAL PERSPECTIVE," Administrative Issues Journal: Vol. 3 : Iss. 1 , Article 4. Publisher version of record available at: https://dc.swosu.edu/aii/vol3/iss 1 /4 


\section{REFERENCE LETTERS AND THE UNINFORMED BUSINESS EDUCATOR: A U.S. LEGAL PERSPECTIVE}

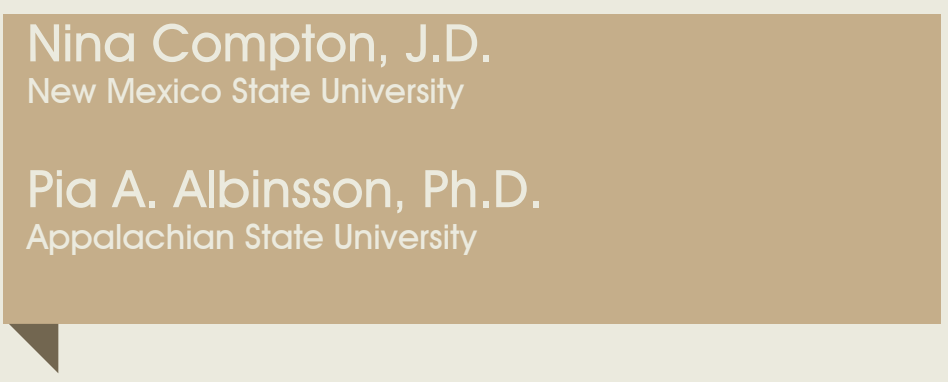

While providing references to students, business professors have to meet dual demands of giving sincere references to prospective employers while avoiding any potential litigation claims of "defamation" and "violation of privacy" from the students. While the approach of providing bare minimum information may seem to mitigate the risk of litigation claims of defamation from former students, it might serve as a potential pitfall for facing "intentional misrepresentation" liability from the prospective employer. This paper addresses these concerns, together with other legal issues U.S. business educators face in this area of potential liability. Suggestions are offered to those who provide references for the purpose of minimizing the possibility of litigation exposure, either from the student or from his future employer.

Keywords: Reference Letters, Business Educator, Defamation, Violation of Privacy, Protection Guidelines

\section{INTRODUCTION}

A $s$ business educators we have two responsibilities and objectives: educate our students and provide industry with a competent and skillful workforce. College students, and especially college graduates, often rely on references from their professors when applying for jobs or to further studies in graduate programs due to lack of industry work experience. Oftentimes professors (and sometimes coaches and spiritual leaders) are the only people that have been in a position to observe the students' characteristics, skills, performance and work ethic. Therefore, it is not uncommon for students to contact their professors, either during their time in college or thereafter, to ask for permission to list the professor as a reference to a potential employer or to ask for a letter of reference for a specific job or graduate program.

Employment references are an important tool that benefits employers with their hiring decisions and assists them to predict the future level of performance for their prospective employees. References also assist in obtaining additional information about job candidates which could not have been retrieved from any other source. Over the past two decades, the demand for letters of reference has increased considerably. Approximately fifty to ninety percent of employers ask for them and utilize them. (See Ziegler, "Employment Law-An Employer's Duty to Third Parties When Giving Employment Recommendations-Davis v. Board of County Commissioners of Dona Ana County", 30 N.M. L. REV. 307,311 , see note $16(2000)$ ). Employment reference information requested generally includes: (1) the applicant's prior employment and educational background; (2) assessment of the applicant's personality and character; (3) assessment of the applicant's work skills and capabilities; and (4) whether or not the reference providers would hire or continue to employ the applicant. Not only employers are asked to provide reference letters, but university professors are frequently called upon to furnish student reference letters to recruiters. Candid and truthful references by professors to potential employers of students serve the dual purpose of assisting a deserving student to get a desired job, as well as helping the employer to make the right choice of applicant for a particular position. However, authors of letters of reference have been subject to a variety of legal actions, both by students and by their prospective employers. While 
honest and forthright references serve the best interest of society, U.S. authors, in particular, can face litigation by students on claims of defamation, invasion of privacy, misrepresentation of facts, and interference with prospective employment.

Authors who attempt to circumvent the potential for lawsuit by providing references bare of basic information, or who have provided glowing recommendations that inflate the status of a poor student have not escaped liability. Such wrongful actions have been subject to claims by the hiring institution for negligent referral and intentional misrepresentation (Davis v. Board of County Commissioners of Dona Ana County, 987 P.2d 1172 (N.M. Ct. App 1999)). While a reference letter that appears neutral on its face may seem to reduce the risk of potential legal action for the author, it can have an adverse effect for the potential employer and on the competency level of employees within the workforce. For example, if a school district hires employees with neutral references, it can be subject to a claim of negligent employment if the person hired demonstrates serious misconduct while on the job. A neutral recommendation could also undermine sought-after personal assets such as intelligence and work ethic of a deserving student and make him appear to be unworthy. Professors are constantly challenged to author meaningful letters of recommendation that serve the best interest of both their students and the prospective employers. This challenge is thwarted by the specter of legal action. An understanding of the law by a review of past case authority in this area of litigation can provide professors with the necessary information to mitigate their risk of liability when providing student references.

Brief guidelines on the specifics of writing reference letters have been published in trade journals, professional magazines and in the popular press (e.g., Aamodt et al., 1993; Schneider, 2000; Siegel \& Garrett, 1998; Weiss, 2004) and more recently via online resources. However, these resources focus mainly on how to write an efficient recommendation letter. In our literature review, we find that there are limited academic research available to aid professors in the process of writing recommendation letters (Barr \& Mcneilly, 2002). While some research has focused on the use of reference letters in academia versus professional fields (Nicklin \& Roch, 2009), other research has investigated the bias in writing reference letters (Grote et al., 2001). For example, Cesi and Peters (1984) examined the effects of confidentiality and found that most professors wrote weaker (and perhaps more truthful) reference letters if they were marked confidential compared to non-confidential. Other researchers have focused on the legal aspects of writing reference letters from the employers' perspective (Clay \& Stephens, 1996; Compton \& Scribner, 1990; Dannin, 2004; FEPG, 2006; Harshman \& Chachere, 2000; Hirschfeld, 2004; McRae, 2007; Peschiera, 2003; Rovella, 1995; Ryan \& Lasek, 1991; Verkerke, 1998). To address this research gap on legal issues in writing reference letters in higher education, we aim to bridge the knowledge on how to best aid our students in getting hired or accepted to a graduate program while highlighting important legal issues to uninformed business professors considering writing reference letters for their current and former students. In addition we provide guidelines for writing references (see Table 1).

\section{LIBEL AND NEGLIGENT MISREPRESENTATION - THE BALANCING GAME}

The term"negligent misrepresentation" is generally defined as a careless or false statement made within a circumstance where caution and care should have been taken. An important case discussing negligent misrepresentation that relates to employment references is Randi W. v. Muroc Joint Unified School District, 929 P.2d 582 (Cal. 1997). (See also Saxton, 1997). In this decision, the California Supreme Court held that it is the duty of the recommendation writer to truthfully represent the qualifications and character of the subject in question. This same finding was determined by the Texas Supreme Court in the case of Golden Spread Council, Inc. v. Akins, 926 S.W.2d 287 (Texas 1996). A different outcome was decided in the New York case of Cohen v. Wales 518 N.Y.S.2d 633 (N.Y Appellate Division 1987). This opinion held that the ultimate decision makers of the hiring decision are responsible in law, rather than the writer who recommends candidates. However, there are many jurisdictions wherein courts have held that negligent representation in a reference letter can make the author of the reference liable to the foreseeable third parties who use these letters for their hiring process. This majority view holds true in jurisdictions throughout the United States (Davis v. Board of County Commissioners of Dona Ana County, 987 P2d at 1180 (N.M. Ct. App. 1999)). Case law has established that employers who make employee recommendations, have a duty to exercise reasonable care to not misrepresent an employee's record whenever such behavior would create a foreseeable risk of physical injury to third parties. 
U.S. courts have recognized recovery on behalf of prospective employers and third persons when letters of recommendation are not truthful or forthcoming (Jener v. Allstate Insurance Co., (1995) No.93-09472 Fla. Cir. Ct.). In this case, the insurance company employer gave a positive reference for an employee who was fired for bringing a gun to work. The prospective employer relied on positive statements in a written reference and hired the individual, who subsequently brought a gun to the new job site and shot several persons in the office cafeteria.

In a more recent decision, the recovery for liability resulting from misrepresentations in reference letters was over 4 million dollars (Kedlec Medical Center v. Lakeview Anesthesia Association, (2008) No. 06-30745). The legal principles that were recognized in recent misrepresentation cases impose liability for writers of letters of reference when such authors are aware of facts that present a substantial and foreseeable risk of harm and are applicable to facultyauthored references. This actionable harm can be to the prospective employer or its employees and other third parties. It should be noted that the courts have also addressed the issue of duty to disclose. It is well-settled that even if a person has no formal duty to disclose a particular fact, in the event one chooses to speak or write, he must communicate enough to prevent the words from being misleading to the recipient (Grozdanich v. Leisure Hills Health Crt., Inc., 25 F. Supp. 2d 953 (1990)).

Negligent misrepresentation lawsuits should not be confused with claims based upon a cause of action of "defamation." The two claims are separate and distinct, though both may play a role in employment reference liability for the author of letters of recommendation. Unlike the aforementioned cause of action based upon the concept of negligent misrepresentation, the term "defamation" is defined as a wrongful and unprivileged injury to a person's reputation (N.M. UJl, Civil, 13-1001, SCRA 1978). A defamatory statement typically has a tendency to render the party about whom it is published to appear contemptible or ridiculous to the public, or hinder others from being associated with him or her (Fikes v. Furst, 134 N.M. 602, 81 P.3d 545 (2003)). The term "libel" is a type of defamatory statement that is expressed in a permanent form, such as in a writing or a photograph. Therefore, a letter of reference that contains defamatory language will constitute a cause of action for libel (Jensen v. Hewlett-Packard Co., 18 Cal. Rptr. 2d. 83 (I993)).

It should be understood that the broad definition of defamation includes both the legal concepts of "libel" and "slander." Traditionally, the term "slander" has been used to identify the oral counterpart of defamation. However, more recently, the distinction between libel and slander has effectively disappeared. Case law provides that the lines of distinction between slander and libel have become so significantly blurred that there are ample reasons for abolishing the distinction between them (Newberry v. Allied Stores, 108 N.M. 424, 773 P.2d 1231, (1989)). For the duration of this paper, libel describes oral or written defamation of a person.

In a well-publicized case that eventually reached the U. S. Supreme court, a former student alleged that a professor's comments in a reference letter defamed him. This case resulted in liability and recovery against the professor (Burt v. Board of Regents of the University of Nebraska, 757 F.2d 242 (10th Cir. 1985)). Subsequent to this landmark case, concerns about defamation suits within the academic community seem to have resulted in a dilution of the content of reference letters. The threat of lawsuits may also have given rise to the practice of professors being more prone to offer verbal references. Though these leave no written trail, they serve neither the applicant's nor the employer's best interest. Telephone inquiries, for example, have become popular because recruiters perceive that reference givers are reluctant to go on record with their comments. Ironically, the absence of documentation, which gives telephoning its appeal, can come back to haunt the unwary responding educator. Unless a professor confirms who is calling and why, he risks being accused of negligent dissemination of reference comments. Moreover, lack of documentation can make defending the actual statement extremely difficult. It should be remembered that in the event the defamatory statements are communicated to the person who is defamed, who then orally repeats the defamation to others, the defamation cannot be brought against the originator of the statements (Gonzales v. Nissan Motor Corp., 58 P.3d 1196 (2002)). Similar protection is afforded to forms of written defamation. In the event a defamatory letter is intercepted by a third person who reads it, this circumstance does not constitute publication or negligent communication of the defamatory statements (Chico v. Frazier, 106 N.M. 733, 750 P.2d 473 (1998)). Therefore, if a professor should send a copy of the reference to the student, in the event that letter contains defamation and it is opened and read by a parent or roommate, then it is not actionable libel for purposes of defaming the student in the eyes of the wrongful recipient. In similar fashion, most jurisdictions provide that intra-corporate communications do not constitute publication and can maintain a protection against liability based on a "need-to-know" reasoning. Accordingly, if a professor is 
referring one of his/her students to the graduate program within the same University, the communication would not result in liability.

As employer demand for written references is not waning, authors of references need to tool themselves against resulting liability from libel actions. Professors face the dual burden of (I) writing recommendations that are informative and therefore less likely to be ignored and (2) protecting student's rights. A brief overview of the historical Supreme Court decisions on libel law in the United States provides a clear understanding of how the law of defamation has developed. In the landmark decision of New York Times v. Sullivan, the U.S. Supreme Court established that defamation requires not only a statement of factual error, but that the plaintiff additionally must have a showing of clear and convincing evidence that the publication was made with actual malice (New York Times v. Sullivan, 376 U.S. 254,84 S. Ct. 710, (1964)). This became known as the "New York Times Rule," and state jurisdictions have since developed their own definitions of actual malice and ways of determining whether actual malice has been shown. Many states now define a defendant's actions as malicious whenever the publication was made by a defendant with knowledge that it was false or with a reckless disregard of its veracity (N.M. UJl, Civil, 13-1009, SCRA 1978). A plaintiff may also prove that a publisher negligently failed to check on the veracity of the communication prior to publication. This finding of "negligence" is appropriate whenever the fact-finder determines that a reasonably prudent person could foresee an unreasonable risk of injury to the reputation of another. The fact-finder must also determine that any person acting with an exercise of ordinary care, would not have acted in the same manner under like circumstances as did the plaintiff (N.M. UJl, Civil, 13-1009, SCRA 1978).

Ten years after the New York Times decision, in Gertz v. Welch Inc., the Supreme Court fine-tuned its evolving libel doctrine and created important new law (Gertz v. Welch Inc., 418 U.S. 323, (1974)). No longer would libel plaintiffs be able to prevail without proving that they were harmed in some way by a defendant's utterance. Moreover, any plaintiff seeking punitive damages, which are designed to punish the author beyond mere compensatory loss, would have to overcome the same obstacles constitutionally mandated for public officials (see Curtis Publishing Co. v. Butts, 388 U.S. 130, 155 (1967); New York Times Co. v. Sullivan 376 U.S. at 285-92, 1964). (See also Compton, Comment, Developing Standards of Care after Time Inc. v. Firestone: Experimentation is Needed, 29 Mercer L. Rev. 841, 842-48, 1978).Furthermore, for a communication to be libelous, it must necessarily be a "false" statement of fact. Statements that constitute communications of opinion rather than statements of fact have historically been treated with particular concern within the context of defamation lawsuits. Courts have adopted the so-called "Gertz Rule," holding that ideas and opinions are constitutionally protected. Statements which are wholly opinions are generally not actionable as defamatory. For example, if a professor writes that "In my opinion the student lacked judgment," then this statement will not be subject to defamation claim. To be actionable under law for defamation, the communication must have one statement of fact, or at least imply that the communication is based on existence of undisclosed facts (Fikes v. Furst, 133 N.M. 146, 61 P.3d 855, (2003)). To determine whether a communication is a mere opinion or a fact, for purposes of defamation, the writing requires an evaluation of (1) the entirety of the publication, (2) the extent that the truth or falsity may be determined without resort to speculation, and (3) whether reasonably prudent persons reading the publication would consider the statement as an expression of opinion or a statement of fact (Fikes v. Furst, 133 N.M. 146, 61 P.3d 855 (2003)). In some jurisdictions, the trial court determines in the first instant if the statement is fact or opinion, under the assumption that the statement is explicitly one or the other (Schuler v. McGraw-Hill Companies, Inc., 989 F.Supp. 1377 (1997)).

In 1990, the U.S. Supreme Court altered the Gertz decision by rejecting the notion that statements of opinion could never be the basis of a libel suit in Milkovich v. Lorain Journal Co., 497 U.S. 1 (1990). This case established that statements of opinion may indeed constitute libel in the event they can be sufficiently proven to be true or false. This case has effectively lessened the opinion defense to libel that had typically been adopted by many lower courts. This finding is a significant development for authors of letters of reference made on behalf of students. Often, pre-printed forms that a business or institution requires to be filled out by the professor may specifically ask for opinion information. One way to circumvent pre-printed questions such as these is for the recommender to give enough specific factual data about the candidate so as to allow the institution to draw its own informed conclusions about the concerns raised by these opinion questions.

It should be remembered that in any libel case the law mandates that the burden of proof befalls the plaintiff. If a 
student suspects his reputation has been harmed by libelous statements, he should identify four basic elements that must be present in order for libel to have occurred: publication to a third party; identification of the plaintiff; a defamatory statement of fact; and actual injury to the plaintiff. If all the elements are identified, the student may legitimately seek redress. The plaintiff must first prove that the offensive statement was published. The term publication has been defined as an intentional or negligent communication to any person other than the person defamed (N.M. UJI, Civil, 13-1003, SCRA (1978)). Publication is an important requirement in order for defamation to be actionable. There can be no defamation if the communication was not published (N.M. UJI, Civil, 13-1003, SCRA (1978)). In mass media cases, wherein the defendant is a newspaper or a magazine, evidence of publication is readily apparent and normally not a matter of dispute. However, libelous content does not necessarily need to be published in a formal sense. Publication may also occur in the aisles of a retail store, at a public meeting, or in a letter (Martinez v. Sears Roebuck \& Co., 81 N.M. 371, 467 P.2d 37, (1970); Dominguez v. Stone, 97 N.M. 211, 638 P. 2d 423, (Ct. App. 1981); Brinich v. Jenka, 106 ALR5th 475, (2000) PA Super 209, 757 A.2d 388)). If a defamatory statement is made to a person who knows that the statement is untrue, publication has not occurred (Fikes v. Furst, 133 N.M. 146, 61 P.3d 855, (Ct. App. 2003); Silverman v. Progressive Broadcasting, Inc., 125 N.M. 500, 954 P.2d 61, (Ct. App. 1998); N.M. UJI, Civil, 131003, SCRA, 1978).

In defamation lawsuits, each of several communications to a third person by the same defendant is a separate publication (Sec. 41-7-1 NMSA, 1978). Once the statement is published for the first time, the clock on statute of limitations will commence. Separate state jurisdictions have statutes of limitations that run for a duration of one to three years from the time of the published defamation (Sec. 37-1-8 NMSA 1978; Jean v. Dugan, 814 F. Supp. 1401, 20 F.3d 255 (1994); Hoke v. Paul, 65 Hawaii 478, 653 P.2d 1155 (1982)). In order to support a claim for defamation, the communication must be concerning, or identifying the plaintiff. Persons can be identified sufficiently by name, address, profession or other characteristics. The plaintiff must prove by a preponderance of the evidence that the communication is concerning the plaintiff. This requirement has been met in circumstances wherein the person to whom it was communicated reasonably understood that it was intended to refer to the named plaintiff. Interestingly, the communication may be concerning the plaintiff even though it is equally applicable to other unnamed persons (N.M. UJl, Civil, 13-1005, SCRA, 1978). Communications must be defamatory and false for libel to occur. Therefore, authors can avoid liability by ensuring that the reference letters contain only truthful assertions of provable veracity.

Interestingly, some recent employment defamation cases hold that a defamatory publication can occur when a plaintiff is under strong compulsion to relate to third parties harmful statements about himself that a defendant might have communicated only to the plaintiff. In one case, for instance, the court recognized a self-publication doctrine for job applicants who felt compelled to divulge to potential employers injurious information that was told to them by previous employers (Lewis v. Equitable Life Assurance Society, 389 N.W.2d 876, Minn., (1986)). A comparable scenario in the educational setting is the following. A campus recruiter asks a student, "I see from your transcript that you received an ' $F$ ' in managerial accounting. Why did that happen?" Under the doctrine of self-publication, the professor might find himself having to defend against a defamation suit if the student, feeling compelled to answer truthfully, were to reply, "The instructor said I cheated on an exam and therefore gave me an 'F' for the course." In this scenario, the professor may need to prove the truth of the cheating accusation to avoid liability, regardless of whether he did not divulge the accusation to any third party.

\section{PRIVILEGE TO DEFAME}

A variety of utterances that would otherwise be classified as actionable defamation are protected under the common law doctrine of "privilege." Under certain conditions, the professor is shielded from liability by the privileged nature of a communication. The theory behind affording privileges is to permit robust freedom of expression without fear of liability in certain settings (see Kalven, "Uninhibited, Robust, and Wide-Open"-A Note on Free Speech and the Warren Court, 67 Mich. L. Rev. 2889, 1968). One commentator believes that the "uninhibited, robust, and wide-open" language was historically the predominant Supreme Court rationale for the defamation privilege (see Anderson, Libel and Press Self-Censorship, 53 Tex L. Rev. 422, 445, 1975). The doctrine of privilege is intended to encourage open discussion on matters that require unfettered interchange of information. State courts have recognized two categories of privilege: "absolute" and "qualified." We focus on qualified privilege for the purpose of this paper since absolute privilege is mostly limited to situations that include judicial proceedings, legislative proceedings, executive 
communications, consent of the plaintiff, spousal communications and political representations (Neece v. Kantu, 84 N.M. 696, 507 P.2d 443 (1978)). The concept of privilege is not the same as confidentiality. The fact that a defamatory statement is made confidentially does not qualify the communication as privileged. Defamatory words do not become privileged merely because they were communicated under conditions of strict confidence.

Qualified privileges exist under a wider variety of circumstances and occur more frequently than do absolute privileges. A "qualified privilege" is one that immunizes an actor from liability only when the defamation exists within the performance of a legal or moral duty. An example of a qualified privilege is the time-honored attorneyclient privilege. A similar qualified privilege is that which attaches to editors of the press for their pre-decisional communications among editors before a story is published (Herbert v. Lando, 568 F.2d 974, 2d Cir., (1977)). Justice Brennen had reasoned as early as 1979 that the law has granted evidentiary qualified privileges to protect "interests and relationships which... are regarded as of sufficient social importance to justify some incidental sacrifice of sources of facts needed in the administration of justice" (Herbert v. Lando, 441 U.S. 153, at 183, (1979)), wherein the Supreme Court reviewed and upheld the actual malice doctrine in the earlier Circuit Court decision (Compton, 1981). Other examples where the courts have extended a qualified privilege include circumstances to protect against mandatory disclosure of journalist's sources in the context of civil litigation (Baker v. F\& F Investment, $470 \mathrm{~F} 2 \mathrm{~d}$ 778, 2d Cir., (1972); see also Compton, Increasing Press Protection from Libel Through a New Public Official Standard: Herbert v. Lando Revisited, 15 Suffolk University Law Review 79, 79-113 (I981).

According to legal experts, our system of freedom of expression functions to promote the search for truth, and to facilitate social change and to achieve personal self-fulfillment (Emerson, Colonial Intentions and Current Realities of the First Amendment, 125 U. Pa. L. Rev. 737, 747 (1977)). In order to encourage honest and truthful disclosures, most state jurisdictions provide a qualified privilege to individuals who make good faith referrals. A qualified privilege extends only to comments pertaining to the performance or public attributes of an individual in question, and does not include comments that relate to his personal life or habits. Also, it exists only for references which are requested and not for voluntary disclosures of information to the potential employer. A qualified privilege is a question of law in the eyes of both federal and state courts (Mahona-Jojanto, Inc., v. Bank of New Mexico, 79 N.M. 293, 442 P.2d 783 (1968); Edwards v. James Stewart \& Co., 82 U.S. App. D.C. 123, 160 F.2d 935 (1947)). Utterances that have been granted a qualified privilege include statements made by an employer about an employee to another person who has a legitimate interest in the matter (Zuniga v. Sears, Roebuck \& Co., 100 N.M. 414, 671 P.2d 662, (1983)). Professors who are responding to an employer query for background checks of students can similarly be insulated from claims of defamation. This immunity will attach in the event the former student signed an agreement with the potential employer to release from liability those who provide information pertaining to his background check (Baker v.. Bhajan, 117 N.M. 278, 871 P.2d 374 (1994)).

The law generally provides that defamatory communications about prospective employees are privileged communications (White v. Blue Cross and Blue Shield of Massachusetts, 442 Mass 64, 809 N.E. 2d 1034 (2004)). Therefore, if a professor is referring a student who has worked under him to a prospective employer, he is immune from defamation as long as the statement is sincere, pertains to the job performance, and serves the human resource needs. This privilege demonstrates a legislative approval of the free flow of information between the former and the prospective employer. Most state statutes provide employers immunity from liability for comments about the job performance of a current or former employee if the employer is acting in good faith. However, such immunity shall not apply when the reference information supplied was knowingly false or deliberately misleading and was made with any type of malicious purpose. The immunity is overcome if there is an abuse of the qualified privilege to defame, such as actual or express malice that is being shown (Trail v. Boys and Girls Clubs of Northwest Indiana, 845 N. E. $2 \mathrm{~d}$ 130 (2006)). In an employment scenario, the former plaintiff/employee must carry the burden of proof to show that his former employer abused its conditional privilege in providing information about the employee to the potential employer (DiMarco v. Presbyterian Healthcare Services, 160 P3d 916 (2007)). Accordingly, a student employee of a professor who can established that the professor's recommendation was written with wanton or reckless indifference and with notions of ill will, spite, or intent to injure, will cause the professor to lose the qualified privilege and be open to suit for recovery of damages.

In a situation where a privilege is offered as a defense in a defamation case, the judge determines whether the 
occasion gives rise to a qualified privilege. In the event that there is a showing at bar that the qualified privilege has been either abused or not abused by clear and convincing evidence, the judge will make that conclusive finding (Mahona- Jojanto, Inc. v. Bank of New Mexico, 79 N.M. 293, 442 P.2d 783 (1968)). However, in cases where the allegation of abuse of privilege is clouded by conflicting facts, the issue of the existence of a qualified privilege becomes a question of fact for the jury (Stewart v. Ging, 64 N.M. 270, 327 P.2d 333 (1958)).

A qualified privilege arises when the communication is made in good faith, the author has a bona fide interest or a duty to perform, and the communication is made to another person with a corresponding interest. If there is no duty to perform or no interest to be served, the communication is not privileged. Interesting case law has gone so far as to establish that even "unsolicited" statements made by a former employer, in a separate document to the attorney general and governor enjoyed a qualified privilege. In such cases, the letter writer may be found to have abused the privilege by acting maliciously or improperly (Baker v. Bhajan, 117 N.M. 278, 871 P. 2d 374 (1994)). Within the scenario of letters authored by professors, a reference would have to consist of relevant statements and be written without malice in order to be protected under the doctrine of qualified privilege. The professor must not provide intentionally false information about the student. The falsity of a communication does not always destroy the qualified privilege. If a false privileged communication is made with probable cause to believe it to be true and without negligence in investigating its truthfulness, there is no liability. Therefore, a qualified privilege generally furnishes protection when good faith is evident and the publication contains relevant information.

The defense of qualified privilege might also be available in circumstances when a professor has occasion to state facts that are outside his personal knowledge and provided by third party comments. It would be necessary for a professor to have personally investigated the veracity of any statement obtained from such third parties that were thereafter passed on in a reference letter. Ordinary negligence in investigating the veracity and truthfulness of third party representations will defeat the qualified privilege. The risk of losing the protection of qualified privilege suggests that professors should abstain from using information they have not personally researched.

The doctrine of qualified privilege can protect even communications of a derogatory nature about the character or attributes of an applicant for employment. This protection is provided upon the qualification that the statements are made in good faith to a potential employer for the employer's benefit. This is particularly true when such statements are made in response to a legitimate request. The privilege fails if the statements are false or inaccurate unless the author had reasonable grounds on which to believe them. It is essential that the professor act reasonably. Although he may not deliberately lie about the qualifications or conduct of the student, he is free in this context to state his honest opinions on the matter. The professor need not avoid commenting on the character and respectability of the student to the extent that such comments are relevant and material to the hiring decision. The test of relevance is whether the communication has reasonable reference to the decision. However, even such relevant statements may lose their privilege if they contain excessive, violent or improper language. Use of intemperate language in a reference communication should be wholly avoided.

A qualified privilege may also be lost by excessive publication beyond the scope of the privilege. Liability can arise if an unprivileged recipient without a legitimate interest obtains the communication. Accordingly, access to reference letters should be strictly controlled. This does not mean that clerical personnel cannot process the communications. The qualified privilege extends to incidental personnel access in the usual course of business. Similarly, communications to entities such as confidential applicant screening boards and selection committees normally receive protection. Whether there has been excessive publication depends on the particular circumstances of each case, and is a question of fact for the jury to infer from the evidence. Generally, the defendant is protected whenever he avoids negligent or deliberate publication outside the scope of the privilege. Adherence to common sense precautions, such as avoiding the use of post cards to send reference communications, are sufficient to protect against loss of the immunity. It is prudent, though not absolutely necessary, to mark the envelope "confidential."

\section{PRIVACY}

While a defamation action protects a person's name and reputation, privacy law affords protection from unlawful intrusions into a person's private life. The "truth" of a statement serves as a defense against a defamation claim, though not against a privacy claim. The tort of invasion of privacy was not recognized until the turn of the century, when a 
young Louis Brandeis wrote that a cause of action should exist to protect one's privacy. After the Brandeis writings introduced the tort, four types of privacy invasions achieved legal recognition: (1) Appropriation of a person's name or likeness, (2) Intrusion upon a person's seclusion or solitude, (3) Publicity that places a person in a false light in the public eye, and (4) Public disclosure of private facts about a person.

Over the last decades, there had been a dramatic shift in attitudes regarding protection of students' rights regarding privacy. Disputes over access to student records were significant enough to warrant federal legislation. The Family Educational Rights and Privacy Act, 20 U.S.C. 1232 (Supp. IV, 1974) (FERPA), also known as the Buckley Amendment, defines conditions under which student records can be accessed. FERPA outlines the duties, obligations, and limitations of the student-institution-professor relationship with respect to privacy issues. Several provisions are of direct concern to professors. FERPA mandates that confidential letters of recommendation for which the student has waived the right of inspection are not accessible by the student. Records in the sole possession of the professor that are not otherwise accessible to other parties are also not accessible to the student. Other provisions within FERPA relate to the release of information to third parties. Except for innocuous items considered "directory information," academic institutions cannot release any information about the student without written consent. Because professors compile evaluative information about students, they are obligated to protect the students' rights and safeguard against unwarranted publication of this type of information. Consider this hypothetical but realistic conversation over lunch between a recruiter and a professor about a student the recruiter had earlier interviewed. In response to the recruiter's inquiries, the professor may advertently or inadvertently disclose protected private information. This can give rise to actionable invasions of privacy regardless of a good faith or well meaning motivation on behalf of the professor. Such situations create a dilemma for the professor since it is not customary to obtain written consent for release of any and all information that a recruiter might request. It is paramount that educators maintain the confidentiality of their private records of students when talking to third parties.

\section{DISCUSSION}

There are solutions for improving the relevance and reliability of reference communications while protecting the rights of students and limiting the legal risks borne by faculty. Authors of references should be careful to limit the content of letters of recommendation to precise, explicit, and unambiguous language. Specific and verifiable information within the recommendation not only enhances the substance of the letter, but is more defensible than generalities. There are ways an educator who cares about students can write meaningful and informative observations in a reference letter so that the student and the potential employer are well served. Some of these methods require conscious planning in order to be effective. Others merely require a modest sensitivity to the needs of the student and the reader. The key is to identify attributes that might not be apparent from the student's resume and transcript. Many reference letters merely make a perfunctory attempt to duplicate information about student course grades. Faced with large numbers of students, the professor may feel that he knows little else about students other than their course grades. Apart from the issue of how well professors should strive to know their students, it is likely that a modicum of extra effort and reflection would evidence additional relevant information about students.

Certain improvements in reference letters are possible with planning. When a student comes to the office to ask for a recommendation letter, it is too late to reconstruct missing information that could easily been easily documented earlier. For example, class records may not clearly reveal the student's writing ability. Separate grades on essay portions of examinations may not be evident, and it is difficult to remember how well each student writes. An easy remedy is to code each writing assignment with an indicator of writing quality. A "+" might mean superior, a "-" might mean poor, and a "ok" might mean average quality. Such a system can be made as detailed as desired and will facilitate commenting on an aspect of performance that is relevant to recruiters.

Simple record keeping provides useful information for improving the content of reference letters. Keeping class attendance records allows professors to fairly and objectively answer the "dependability" and "reliability" questions that often appear on reference forms. Homework records also serve as indicators of the level of student commitment. Other informal notes jotted down during or after class can be helpful later. These might include observations about a student's ability in oral expression, participation in class discussions, preparation for class, an insightful problem solution, or other items that are difficult to recall later. 
Impressions obtained during office hour visits by students are often useful. Students, whose questions are well organized, for example, are exhibiting different behavior from those who ask, "Would you please go over Chapter 18 again?" Advisee counseling sessions are particularly revealing of a student's organizational skills and professional commitment. A quick notation in the advisee's file is an easy task.

The professor who works with student organizations might find it helpful to take brief notes on specific contributions made by individual students. For example, it might be difficult to remember that a particular student effectively chaired the community-service committee; but this indicator of leadership ability would provide useful information on a reference form. Just a few notes of this type would substantially improve reference letters without requiring substantial time or energy.

An additional technique for constructing useful information on behalf of students is to request them to write an autobiographical sketch. It is also appropriate to ask for a copy of the student's resume to add content to the reference letter. Aids such as these, in addition to reminding the professor of the student's activities, can also serve as indicators of articulation and organization skills.

Some student information is always available through the normal process of gathering exam and assignment scores to determine course grades. Certain patterns observable in the "raw data" underlying the course grades may help to create a more informative reference letter. For instance, a pattern of steady improvement during the course would not be evident to someone who is relying on a transcript for information about student performance. A high degree of variability in performance or, conversely, a high degree of consistency is worth a comment. If the professor knows of personal circumstances that have likely affected the student's work, a note to that effect is useful to the evaluator. Additionally, it may be appropriate to report the student's rank in the class. This information is usually not evident from the course grade. There is a considerable amount of "reading between the lines" involved in using reference letters. The absence of a comment might be construed as a negative observation. Therefore, a reference that contains a considerable amount of reliable and useful information is more able to provide an accurate understanding of a student's characteristics.

The law generally recognizes an absolute privilege to a person responding to a reference request where the plaintiff has invited the inquiry. Courts also generally extend at least a qualified privilege to responses absent plaintiff consent. In either circumstance, however, prudence dictates that professors take certain precautions to avoid the possibility acting in such a manner as to lose the privilege (see Table 1, section A).

Adhering to this delineated list of recommendations can enable professors to create useful letters of reference. However, it remains a vigilant task for professors to balance the dual demands of providing sincere references to prospective employers while avoiding any potential litigation claims from the students. Professors should remain on their guard and ever watchful of student rights. Additional advice for educators to heed includes some further guidelines for student references (see Table 1, Section B). In addition to the above suggestions (Peschiera, 2003) recommends that professors add the phrase "without legal responsibility," to a reference letter to protect against accusations of deceit, however this phrase does not protect against either defamation or negligence.

Another aspect for professors to consider is to educate students in the process of obtaining a reference (Petress, 1999; Range et al., 1991). Professors are sometimes caught in a bind, as educators our objective is to help guide our students and facilitate in the job searching process by preparing the students for life after college. However, sometimes we may not feel comfortable giving certain students a helping hand due to their less than stellar performance or lack of work ethic. Other times professors are more than comfortable to offer a recommendation of a student to a third party. The laws of defamation and libel may not be all that familiar to business professors and especially not recent PhDs and Assistant Professors who have just themselves received an academic position (most likely with the assistance of their professors in addition to their own credentials).

Oftentimes students are unaware of what their current or former professors need in terms of supporting material and the focus of the letter in order to write a quality reference letter. It is clear from our own experiences as well as documented in the literature that students highly differ in their view of reference letters (e.g., from highly valued and useful for employers and students to completely useless (Payne et al., 2006). 


\section{Table 1}

\section{Guidelines for Reference Letters}

\section{Section A: Precautions to avoid the possibility to lose absolute privilege}

- Obtain the student's written consent to release information.

- Release only written information.

- Communicate by closed letter, addressed to an authorized person, not "to whom it may concern"

- Release only that information that can be supported by objective data and that is personally known to be correct.

- Release only information that is relevant to the employment decision and that can reasonably be proven.

- Avoid excessive or abusive language.

- Always act under a rightful purpose and avoid wrongful motives. Decline to furnish reference information when there might be a problem in these areas.

\section{Section B: General policy approaches}

- Discuss everything good and bad about the student.

- Give reference letters only to students who are good and deserving.

- Provide only material facts like student name, course of study, etc.

- Practice different policy in different situations.

\section{CONCLUSION}

Reference forms and letters written by professors on behalf of students continue to play a central role in hiring decisions. However, writing such letters can expose professors to legal redress under privacy and defamation laws. A professor may find that he devotes considerable time to writing references that have the potential for significant legal consequences. Since the demand for these references does not appear to be waning, it is in the interests of the student and the prospective employer that these letters be made as informative as possible, while safeguarding against resultant liability. An understanding of the theory and legal reasoning of the past court decisions in defamation and invasion of right to privacy claims can afford substantial protection for the concerns of professors. This paper has discussed some of the essential factors which have determined the outcome of past legal actions taken against authors of references. While the potential to be held liable for defamation or invasion of privacy still remains, there are numerous safeguards which can assist a reference to satisfy legal requisites and avoid grievances by students.

A number of precautionary measures are suggested in the paper that can aid writers of references to mitigate their risks of liability for both libel and misrepresentation. Authoring relevant and reliable references to the correct authority enables professors to provide accurate job placement information about student applicants in the workforce. This serves the best interests of the business community and society as a whole. Certain procedures that require little marginal effort can offer specific useful information about student performance that, because of its objectivity and factual nature is largely invulnerable from defamation lawsuits. Prudence and caution by professors who have access to private student records can prevent the wrongful dissemination of proprietary information within recommendation letters, and prevent invasion of privacy lawsuits by students. Professors have the obligation to provide a truthful, sincere, and relevant representation of facts pertaining to the qualifications of a reference seeker. This can be accomplished without legal consequences if performed within the parameters that the law allows. 


\section{REFERENCES}

20 U.S.C. 1232 (Supp. IV, 1974) (FERPA)

Aamodt, M. G., Devon A. B., \& Whitcomb, A. J. (1993). Predicting performance with letters of recommendation, Public Personnel Management, 22, 81-90.

Anderson, Libel and Press Self-Censorship, 53 Tex L. Rev. 422, 445 (1975).

Baker v. Bhajan, 117 N.M .278, 871 P.2d 374 (1994).

Baker v. F \& F Investment, 470 F.2d 778 (2d Cir. 1972).

Barr, T. F. , \& McNeilly, K. M. (2002), The value of students' classroom experiences from the eyes of the recruiter: Information, implications and recommendations for marketing educators. Journal of Marketing Education, 24, 168-173.

Brinich v. Jenka, 106 ALR 5th 475, (2000).

Burt v. Board of Regents of the University of Nebraska, 757 F.2d 242. (10th Cir. 1985).

Chico v. Frazier, 106 N.M. 733, 750 P.2d 473 (1988).

Clay, J. M., \& Stephens, E. C. (1996). The fefamation trap in employee references. Cornell Hotel and Restaurant Administration Quarterly, 37 (April), 18-24.

Cohen v. Wales, 518 N.Y.S.2d 633 (N.Y Appellate Division 1987).

Compton, D. J. (1981). Increasing press protection from libel through a new public official standard: Herbert v. Lando Revisited. Suffolk University Law Review, 15, 79, 79-113.

Compton, N., \& Scribner, E. (1990). Furnishing employee references - some cautions to the practitioner. Journal of Accountancy, November, 151-152.

Curtis Publishing Co. v. Butts, 388 U.S. 130, 155 (1967).

Dannin, E. (2004), Letters to the editor - what to say in a job reference. The Chronicle of Higher Education, 50 (48), B14.

Davis v. Board of County Commissioners of Dona Ana County, 987 P.2d 1172 (1987).

Davis v. Board of County Commissioners of Dona Ana County, 987 P.2d 1180 (1987).

DiBiasio v. Brown \& Sharpe Mfg. Co., 525 A.2d 489, 491 (RI.1987).

DiMarco v. Presbyterian Healthcare Services, 160 P.3d 916 (2007).

Dominguez v. Stone, 97 N.M. 211, 638 P. 2 d 423 (N.M App. 1981).

Edwards v. James Stewart \& Co., 82 U.S. App. D.C. 123, 160 F.2d 935 (1947).

Emerson, Colonial Intentions and Current Realities of the First Amendment, 125 U. Pa. L. Rev. 737,747 (1977).

FEPG - Fair Employment Practices Guidelines (2006), Five (or More Ways You can be Sued for Writing (or Not Writing) Reference Letters, Aspen Publishers, Number 614 (July), 2-4.

Fikes v. Furst, 134 N.M. 602, 81 P.3d 545 (2003).

Fikes v. Furst, 133 N.M. 146, 61 P.3d 855, (N.M. App. 2003).

Gertz v. Welch Inc., 418 U.S. 323 (1974).

Gonzales v. Nissan Motor Corp., 58 P.3d 1196 (2002).

Golden Spread Council, Inc. v. Akins, 926 S.W.2d 287 (1996).

Grote, C.L., Robiner, W.N., \& Haut, A. (2001). Disclosure of negative information in letters of recommendations: Writers' intentions and readers' experiences. Professional Psychology: Research and Practice, 32(6), 655-661. 
Grozdanich v. Leisure Hills Health Crt., Inc., 25 F. Supp. 2d 953 (1990).

Harshman, E., \& Chachere D. R (2000). Employee references: Between the legal devil and the ethical deep blue sea. Journal of Business Ethics, 23, 29-39.

Herbert v. Lando, 568 F.2d 974 (2d Cir. 1977).

Herbert v. Lando, 441 U.S. 153, at 183. (1979).

Hirschfeld, S. J. (2004). The dangers of employment references. The Chronicle of Higher Education, June 25, p. B11.

Hoke v. Paul, 65 Hawaii 478, 653 P.2d 1155 (1982).

Jean v. Dugan, 814 F. Supp. 1401, 20 F.3d 255 (1994).

Jener v. Allstate Insurance Co., No.93-09472 Fla. Cir. Ct. (1995).

Jensen v. Hewlett-Packard Co., 18 Cal. Rptr. 2 d. 83 (1993).

Kalven, "Uninhibited, Robust, and Wide-Open"—A Note on Free Speech and the Warren Court, 67 Mich. L. Rev. 2889 (1968).

Kedlec Medical Center v. Lakeview Anesthesia Association, No. 06-30745 (2008).

Lewis v. Equitable Life Assurance Society, 389 N.W.2d 876 (Minn. 1986).

Mahona-Jojanto, Inc. v. Bank of New Mexico, 79 N.M. 293, 442 P.2d 783 (1968).

Martinez v. Sears Roebuck \& Co, 81 N.M. 371, 467 P.2d 37 (1970).

McRae, Andrea (2007), Providing References, HR Professional, 24 (4), 32.

Milkovich v. Lorain Journal Co., 497 U.S. 1 (1990).

Neece v. Kantu, 84 N.M. 696, 507 P.2d 44 (1973).

Newberry v. Allied Stores, 108 N.M. 424, 773 P.2d 1231 (1989).

New York Times v. Sullivan, 376 U.S. 254, 84 S. Ct. 710 (1964).

New York Times v. Sullivan 376 U.S. at 285-92.

Nicklin J. M., \& Roch, S. G. (2009). Letters of recommendation: Controversy and consensus from expert perspectives. International Journal of Selection and Assessment, 17(1), 76-91.

NMSA 1978 Sec. 37-1-8.

NMSA 1978 Sec. 41-7-1.

N.M. UJ, Civil, 13-1001, SCRA 1978.

N.M. UJ, Civil, 13-1003, SCRA 1978.

N.M. UJI, Civil, 13-1005, SCRA 1978.

N.M. UJI, Civil, 13-1009, SCRA 1978.

Payne, B. K., Appel, J., Smith, D. H., \& Hoofnagl, K. (2006), Student's perceptions of reference letters. College Student Journal, 40(4), 814-820.

Peschiera, R. (2003). References become a legal minefield. Director, 56(11), 40.

Petress, K. C. (1999). Letters of recommendation: Their motive and content. College Student Journal, 33(4) 485487.

Randi W. v. Muroc Joint Unified School District, 929 P.2d 582 (1997). 
Range. L. M., Manyhert, A., Walsh, M. L., Hardin, K. N., Ellis, J.B., \& Craddick R. (1991). Letters of recommendations: Perspectives, recommendations, and ethics, 22(5), 389-392.

Rovella, D. (1995), Laws may ease the risky business of job references. National Law Journal, 18, B1.

Saxton, B. (1997),.Employment references in California after Randi W. v. Muroc Joint Unified School Districts: A proposal for legislation to promote responsible employment reference practices. Berkeley Journal of Employment and Labor Law, 18(2), 240-273.

Schneider, A. (2000). Why you can't trust letters of recommendation. The Chronicle of Higher Education, June 30, Section: The Faculty Page:A14 Retrieved from http://chrnoicle.com/article/Why-You-Cant-Trust-Letters-of2132/.

Schuler v. McGraw-Hill Companies, Inc., 989 F.Supp. 1377 (1997).

Siegel, R. A., \& Garrett, A. E. (1998). Giving employee references: Potential pitfalls and protections. Los Angeles Business Journal, Jan 12.

Silverman v. Progressive Broadcasting, Inc. (1998) 954 P.2d 61, 125 N.M. 500 (N.M. App.).

Stewart v. Ging, 65 N.M. 270, 327 P.2d 333, 335 (1958).

Trail v. Boys and Girls Clubs of Northwest Indiana, 845 N. E. 2d 130 (2006).

Verkerke, J. H. (1998). Legal regulation of employment reference practices. The University of Chicago Law Review, 65(1), 115-178.

Weiss, G. G. (2004). Should you give references? Medical Economics, 81(4), 46-57.

White v. Blue Cross and Blue Shield of Massachusetts, 442 Mass 64, 809 N.E. $2 d 1034$ (2004).

Ziegler, J. K. (2000) Note, Employment Law-An Employer's Duty to Third Parties when Giving Employment Recommendations-Davis v. Board of Commissioners of Dona Ana County, 30 N.M. L. Rev. 307, 2000.

Zuniga v. Sears, Roebuck \& Co., 100 N.M. 414, 671 P.2d 662 (N.M.1983).

\section{ABOUT THE AUTHORS}

Nina H. Compton (ncompton@nmsu.edu) is a Professor Emeritus of Business Law in the Business College and Honors College of New Mexico State University. She presently teaches legal studies courses from a Compendium of her own national business publications and her law review articles published by the University of New Mexico School of Law. She is nationally recognized for her numerous teaching awards, holds an international reputation for her service on the Oxford Round Table of Manchester College, and is published in the Forum on Public Policy of the University of Oxford in the area of gender discrimination law. Compton holds a Juris Doctor degree from the Delaware Law School of Widener College and a Master of Arts degree from the University of New Mexico.

Pia A. Albinsson (albinssonpa@appstate.edu) received her Ph.D. from New Mexico State University and is Assistant Professor of Marketing at Appalachian State University's Walker College of Business. Her research encompasses sustainable consumption practices, alternative disposition behavior, advertising effectiveness, on- and offline communities and consumer activism. She has written several book chapters and has been published in a number of journals, including Journal of Consumer Behaviour, European Journal of Marketing, Journal of Public Policy and Marketing, Journal of Online Learning and Teaching, and Advances in Consumer Research. 